J. Product. \& Dev., 26(4): 923- 938 (2021)

\title{
THE EFFICIENCY OF PROPOLIS AS ACARICIDE
}

\author{
Shimaa M. EL-Hadek, Ahmed A. Romeh, Nabil A.Omar, Hamza M.EL- \\ Sharkawy \\ Plant Production Dep., Faculty of Technology \& Development, Zagazig \\ University, Egypt. \\ e mail:ahmedromeh2006@yahoo.com
}

\section{ABSTRACT}

Propolis is a dark yellow or brownish resinous mixture of several compounds; include the phenolic, flavones, coumarines, and many other phenolic compounds. Mites, especially Tetranycus urticae koch and the parasitic mites Varroa destructor Anderson and Trueman (Pasositic) are unique among arthropods in that it is resistant to a wide range of acaricides and insecticides. Therefore, propolis efficiency was tested as ethanol extract (polar), hexane extract (non-polar) against Eutetranychus africanus (Tucher) and nano-emulsion of propolis against Tetranychus urtica and $V$. destructor.

The results showed that, at the LC50 and LC90 ethanol extract was more toxic to adult females of E. africanus than hexane extract. Adult females of T. urticae were susceptible to the nano-emulsion of propolis. The LC50 and The LC90 reached $4.10 \%$ and $41.12 \%$ to the nanoemulsion of propolis. The biological aspects of two species of mites (T. urticae and E. africanus) were more affected by the three forms of propolis. In the winter season, the efficiency percentage of nano-emulsion of propolis at $4 \%$ reached $100 \%$ compared to control. While, in the autumn season, the efficiency percentage reached $95.62 \%$ at the first spray and reached $94.85 \%$ through 15 days of the first spray compared to 54.16 in control experiment.

Conclusively, from these results it be concluded that, propolis can be used as acaricides against plant mites, as well as against the Varroa colonies in honeybees in the form of nano-emulsion.

Keywords: Propolis, Nano emulsion, Eutetranychus africanus, Tetranychus urtica, Varroa destructor.

\section{INTRODUCTION}

Honey bees (Apis mellifera L.) are the most important crop pollinator species. According to researching over 300,000 beehives play honeybee an 
important role in pollinating crops during the flowering season. (Munawar et al., 2009), and that the beneficial effect on crops such as canola includes seed productivity (Rosa et al., 2011; Costa et al., 2019).

Propolis (bee glue) is a dark yellow or brownish resinous mixture of several compounds, especially flavonoids and phenolic acid derivatives, which are collected from various trees such as eucalyptus by honeybees by mixing saliva and beeswax with the secretions collected from different plant sources as tree buds, sap flows, are used to build and protect a beehive (Daugsch et al., 2008; Bogdanov and Bankova, 2017). Sealing holes in their honeycombs, smoothing the inner walls of a beehive, and protecting the entrance from intruders are just a few examples (Fahmy et al., 2020). The biological activity of propolis is due to its high resin content as phenolic compounds (Bogdanov and Bankova, 2017). Each cell of propolis is slightly different; the final composition of the propolis is 50 percent resin, 30 percent waxes, 10 percent essential oils, 5 percent pollen, and 5 percent plant debris (Bogdanov and Bankova, 2017). More than 300 compounds, including volatile organic compounds, flavonoid a glycanes, phenolic acids and their esters, phenolic aldehydes, alcohols and ketones, sesquiterpenes, quinones, coumarins, steroids, and amino acids, have been isolated from propolis from various geographical regions around the world. (Alencar et al., 2007). Flavonoid components of propolis, which collected from several plants, have insecticidal effects (König and Dustmann, 1988). Most of the compounds from isolated propolis include the phenolic flavones, coumarines, and many other phenolic compounds have reducing activity, hydrogen-donors and metal chelating properties. It is known that propolis possesses anti- microbial, antioxidative, anti-ulcer, anti-tumor and acaricidal activities (Lotfy, 2006; Ararso and Legesse, 2016; Alexandra et al., 2019; Moukarab, 2020).

Mites, especially T. urticae and Varroa destructor are unique among arthropods in their wide range of resistance to acaricides and insecticides (Van Leeuwen et al., 2010; Monteiro et al., 2015, Santamaria et al., 2020). The rapid development of resistance to a variety of acaricides may be due to life cycle, reproductive mode, and high biotic potential favour (Stumpf and Nauen, 2001, Monteiro et al., 2015). With regard to Varroa parasite, the use of pesticides to control bee pests causes a number of issues, including increased treatment and labor costs, toxicity risks to beekeepers and bees, risk of contaminating hive products (Ararso and Legesse, 2016), buildup of residues in bee products (Damiani et al., 2010) and the emergence of resistant Varroa parasite strains as a result of the pesticides' widespread use such as resistant to fluvalinate, 
flumethrin, coumaphos and amitraz (Spreafico et al., 2001, Skerl et al., 2011; González-Cabrera et al., 2013).This led to discover new treatment strategies that minimize these problems. Natural products having components with various modes of action might provide effective solution to the problem of varroatosis (Garedew et al., 2002), such as natural and green nano particles from Plant extracts and propolis (bee glue). propolis can be considered a social immune defense mechanism and is therefore potentially important to maintaining colony health (Drescher et al., 2017).

Based on the origin of the propolis, the water-soluble components make up about 2.5-6.5\% of the total. (Neunaber, 1995).Therefore, Propolis efficiency was tested as ethanol extract (polar), hexane extract (non-polar) against $E$. africanus. Moreover, propolis was prepared in other form as nano emulsion, which is characterized by its high ability to dissolve in water and oil and its high ability to penetrate the different parts of the beehives due to the small size of its droplets and recording both narcosis and mortality.

So, the miticidal activity of nano-emulsion of propolis against $T$. urticae and Varroa destructor were studied. Also, the antibacterial properties of nanoemulsion of propolis against the bacteria Staphylococcus aureus were also studied.

\section{MATERIALS AND METHODS}

\section{Mite cultures:}

The experiments were carried out using adult females of Tetranychus urticae and Eutetranychus africanus, which collected form castor been leaves and margosa trees, respectively at Zagazig region. Pure cultures of mites started with a small number of females which were reared in the laboratory condition on sweet potato, Iponoea batatasunder constant temperature $\left(28 \pm 2^{\circ} \mathrm{C}\right)$ and relative humidity $(65 \pm 5 \%)$.

\section{Preparation of hexane and ethanol extraction for propolis}

Hexane extract as nonpolar and ethanol extract (70\%) as polar extract were used to extract propolis by homogenate powder samples of propolis at ratio (9 extract: 1 propolis) for $2 \mathrm{hrs}$ in a shaker then filtered on filter paper No.1, then extracted in a rotary vacuum evaporator (Buch company, Germany) at $60{ }^{\circ} \mathrm{C}$ for 2 hrs. to weight constancy (Garedew et al., 2002; Cunha et al., 2004). The yield of extraction was estimated for preparation the concentrations which used in toxicity experiment. The extraction yield is equal to weight of propolis extract (g) / weight of raw propolis (g) x 100\%. 


\section{Preparation nano-emulsion of propolis}

The nano-emulsion was prepared according to Seibert et al., (2019) by phase inversion emulsification method (PIE) with some modification. The formulation was consisted of corn oil $(5.0 \% \mathrm{w} / \mathrm{w})$ as oil phase, distilled water $(84.0 \% \mathrm{w} / \mathrm{w})$ as aqueous phase, carboxymethyl cellulose $(3.0 \% \mathrm{w} / \mathrm{w})$ and polysorbate 80 (tween 80$)(7.0 \% \mathrm{w} / \mathrm{w})$ and propolis $(1 \% \mathrm{w} / \mathrm{w})$. Carboxymethyl cellulose $(\mathrm{CMC})$ is a hydrocolloid with surface activity that can act as an emulsifier in oil-in-water emulsions; however, its primary role in the aqueous phase is as a structuring, thickening, or gelling agent. The oil phase, which included the surfactants and the extract, was heated to $75 \pm 2{ }^{\circ} \mathrm{C}$. Using a mechanical stirrer, the water phase was heated to the same temperature and flown into the oil phase while maintaining the agitation speed at $600 \mathrm{rpm}$ until complete cooling $\left(25^{\circ} \mathrm{C}, 30 \mathrm{~min}\right)$. The resulting emulsion was subjected to ultrasonicator bath (Codyson, CD-4820, $42 \mathrm{kHz}$, China) for 24 min at room temp.

\section{Toxicity tests against Eutetranychus africanus and Tetranychus urtica}

The concentrations used in ethanol and hexane extract of propolis against adult stage of E. africanus were 50\%, 25\%, 12.50\%, 6.25\%, and 3.125\%. Leaf discs of sweet-potato $(2.5 \mathrm{~cm}$ in diameter) were prepared for adult stage of $E$. africanus. Leaf discs treated with fifth concentrations of each extracts using leaf dipping technique. On the other hand, eight concentrations of nano-emulsion of propolis $(0.36 \%, 0.73 \%, 1.56 \%, 3.12 \%, 6.25 \%, 12.50 \%, 25$ and $50 \%)$ as emulsifying solution were tested against $T$. urtica with the same technique used for E. africanus. The control mites were held using distilled water. Four sweet potato leaf discs (1-inch in diameter) were placed on wet cotton wool in a Petri dish to each concentration. Each disc was considered as a replicate contained 10 adults. The individuals were maintained under laboratory condition $\left(28^{\circ} \mathrm{C} \pm 2^{\circ} \mathrm{C}\right)$ and approximately $70 \pm 5 \%$ R.H. The number of live and dead mites of adult females was assessed daily for 24 and 48-hrs. Mites were considered dead if their appendages did not move when prodded with a fine paint brush. Mortality counts of adult females were corrected using Probit analysis to determine the lethal concentration $\left(\mathrm{LC}_{50}\right)$ value, using the Biostat, probit analysis program version 3.2YAG.

\section{Biological effect}

Adult females of the same age of E. urticae or T urtica have been set individually on sweet-potato leaf-discs resting on wet cotton wool in a Petridish. Potter tower sprayed the Petri-dishes with the respective extract at the $\mathrm{LC}_{50}$ levels, and twenty replicates were made. The different effects on the biological 
aspects were estimated. Analysis of variance (ANOVA) was carried out for the obtained data according to the method of Waller and Duncan (1969).

\section{Toxicity test against Varroa destructor}

The field part of the present experiment was tested in an apiary located at Ghazala farm, Ghazala, Sharkia Governorate, Egypt. Colonies of hybrid Italian honeybees, (Apis mellifera L). naturally heavily infested by varroa individuals were treated during winter season of 2021 (1-January) and during autumn season, 9-August and the treatment were repeated after 15-days, (24-August) with LC50 of T. urticae (4\%) of nano-emulsion of propolis. Three colonies were used for the treatment and the three untreated colonies were left as control. Dead varroa mites fallen on the bottom board, covered with sheet of white paper with a layer of sticky substances (vaseline, oil) were collected and counted in all tested colonies (treatments and Control) at 7days after the treatments through winter season and at 7days through the first spray of autumn season, while at $1^{\text {st }}$ and $7^{\text {th }}$ through the second spray of autumn season. At each count, the old sheets were taken out for counting and replaced with new vaseline oil.

Relative efficacy of the control substance $\%=[$ (number of mites spilled after 7-days of control - average natural precipitation before control) / number of mites fallen after 7-day of control) $\times 100$ ].

\section{RESULTS AND DISCUSSION}

\section{Acaricidal activity}

Table (1) and Fig.1 show the toxicity of ethanol extract and hexane extract of propolis against adult females of $E$. africanus and the toxicity of nanoemulsion of propolis against $T$. urticae after 48 hour of exposure. The results reveal that, at the $\mathrm{LC}_{\mathbf{5 0}}$ and $\mathrm{LC}_{\mathbf{9 0}}$ ethanol extract was more toxic to adult females of $E$. africanus than hexane extract. The $\mathrm{LC}_{\mathbf{5 0}}$ reached $3.98 \%$ and $5.75 \%$ for ethanol and hexane extract of propolis. While, the $\mathrm{LC}_{90}$ reached $18.55 \%$ and $27.99 \%$ for ethanol and hexane extract of propolis, respectively. At $\mathrm{LC}_{50}$ the toxicity of ethanol extract of propolis was 1.44 time more toxic to adult females of E. africanus than hexane extract of propolis, after 48 hours.

Several studies have shown that the two-spotted spider mite, Tetranychus urticae Koch is one of the most dangerous pests and causes severe damage to vegetables, and crops, because of its short life cycle, high offspring production, and ability to develop pesticide resistance (Rincón et al., 2019; Santamaria et al., 2020; El-sayed and Emam, 2021). Therefore, a new trend was tested, which is nano-emulsion of propolis, which is characterized by its containing of complex 
Table (1): Toxicity of ethanol and hexane extracts of propolis to adult females of Eutetranychus africanus and nano- emulsion of propolis against adult females of Tetranychus urticae

\begin{tabular}{|c|c|c|c|c|c|c|c|c|c|}
\hline \multirow[t]{3}{*}{ Parameters } & \multicolumn{6}{|c|}{ Eutetranychus africanus } & \multirow{2}{*}{\multicolumn{3}{|c|}{$\begin{array}{c}\text { Tetranychus urticae } \\
\begin{array}{c}\text { Nano- emulsion of } \\
\text { propolis }\end{array} \\
\end{array}$}} \\
\hline & \multicolumn{3}{|c|}{$\begin{array}{c}\text { Ethanolic extract of } \\
\text { propolis }\end{array}$} & \multicolumn{3}{|c|}{$\begin{array}{c}\text { Hexane extract of } \\
\text { propolis }\end{array}$} & & & \\
\hline & $\begin{array}{l}\mathrm{LC}_{50} \\
(\%)\end{array}$ & $\begin{array}{l}L^{2} C_{90} \\
(\%)\end{array}$ & Slope & $\begin{array}{l}\mathrm{LC}_{50} \\
(\%)\end{array}$ & $\begin{array}{l}\mathbf{L C}_{90} \\
(\%)\end{array}$ & Slope & $\begin{array}{c}\mathrm{LC}_{5} \\
0 \\
(\%) \\
\end{array}$ & $\begin{array}{l}\mathbf{L C}_{90} \\
(\%)\end{array}$ & Slope \\
\hline 48-hrs & 3.98 & 18.35 & 1.93 & 5.75 & 27.99 & 0.79 & 4.10 & 41.12 & 0.67 \\
\hline Toxicity index at & 100 & 100 & - & 69.22 & 65.56 & - & & & \\
\hline $\begin{array}{l}\text { Relative potency } \\
\text { at }\end{array}$ & 1.44 & 1.53 & - & 1.0 & 1.0 & - & & & \\
\hline
\end{tabular}

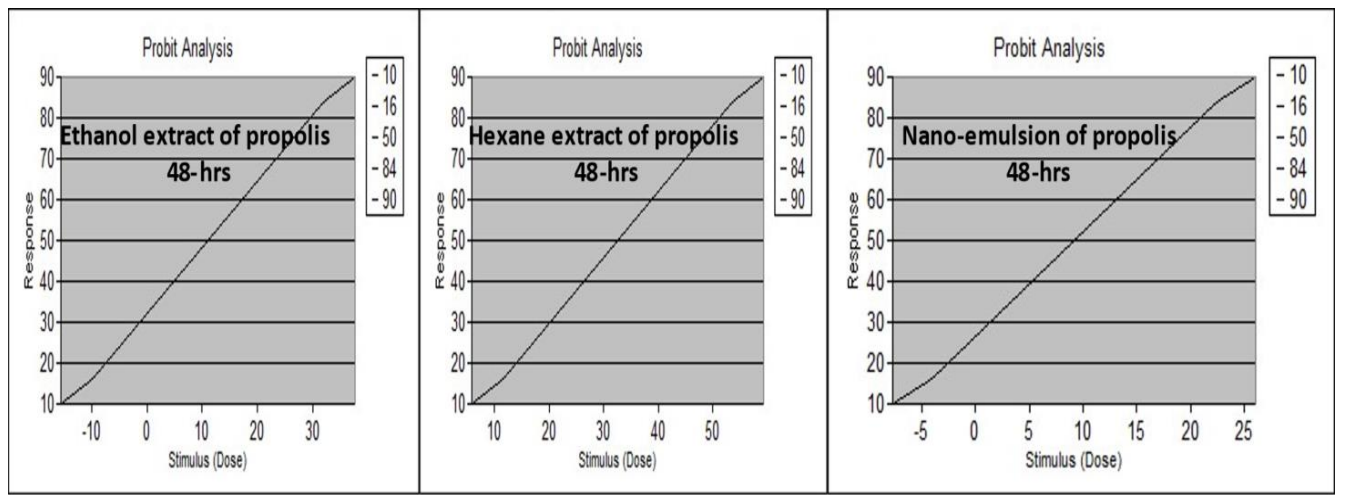

Figure (1) The LDP line of ethanol and hexane extracts of propolis to adult females of Eutetranychus africanus and nano- emulsion of propolis against adult females of Tetranychus urtica

mixture of different compounds and small size of its particle size. Table (1) showed that the adult females of $T$. urticae which is resistant to many toxic substances was susceptible to the nano-emulsion of propolis. The $\mathrm{LC}_{50}$ and The $\mathrm{LC}_{90}$ reached $4.10 \%$ and $41.12 \%$ to the nano-emulsion of propolis. This $\mathrm{LC}_{50}$ was tested after that in the field against $V$. destructor. Propolis (bee glue) is a common bee product; it is a complex mixture of different compounds collected by honeybees from various plants, mixed with wax, and used in the construction and preservation of the bee-hive (Ghisalberti, 1979). The mortality rate was $98.27 \pm 0.57 \%$ for eggs and $98.25 \pm 0.37$ and $97.42 \pm 0.39 \%$ for larva and nymph stages of $T$. urticae at the concentration of $2000 \mathrm{ppm}$ of ethanolic extract of propolis under greenhouse conditions comparing with the control (El-sayed and Emam, 2021).The same authors showed that, the high mortality percentage 
was observed after $72 \mathrm{~h}$ of treatment of all concentrations and all stages. Some flavonoid propolis components, such as phenolic compounds (flavanones, flavones, flavonols, caffeic acid phenethyl ester (CAPE), cinnamic acid, and dihydro-flavonols) have insecticidal properties as natural compounds (Mehta et al., 2018; Karapetsas et al., 2019; El-sayed and Emam, 2021). These substances are known for their ovicidal, antifeedant, repellent, and killing behavior against arthropod pests (Tomczyk and Suszko, 2011).

\section{Biological activity}

Table (2) show the changes in some biological activity of E. africanus after exposure to hexane and ethanol extracts of propolis and T. urticae after exposure to nano emulsion of propolis. Data revealed that, eexane and ethanol extract of propolis highly significantly shortened the adult longevity of $E$. africanus, while nano emulsion of propolis showed highly significance and shortened the adult longevity of $T$. urticae compared whith of the control. Also, preoviposition period, oviposition and postoviposition period were significantly affected by the different treatments of the propolis. On the other hand, hexane and ethanol extract of propolis prolonged pronouncedly the incubation period for E. africanus, and nano emulsion of propolis induce the same effect for T. urticae compared to that of the control.

Moreover, total immature for both mites significantly prolonged as affected with the three forms of propolis. Moreover, life cycle and generation time significantly prolonged as affected by the treatments compared with control. Romeh and Omar, (2003) mentioned that, Beauveria bassiana and Metarhizium anizopliae against $T$. uricae and $E$. extract of propolis prolonged pronouncedly the incubation period forE. africanus, and nano emulsion of propolis induce the same effect for $T$. urticae compared to that of the control. Moreover, total immature for both mites significantly prolonged as affected with the three forms of propolis. Moreover, life cycle and generation time significantly prolonged as affected by the treatments compared with control. Romeh and Omar, (2003) menthioned that, Beauveria bassiana and Metarhizium anizopliae against T. uricae and E. africanus were prolonged pronouncedly the preoviposition period and incubation period, while shortened the oviposition period, number of eggs/female and longevity. El- Sayed et al., (2009) reported that when compared to the control, the oil of Mentha spicata L. shortened the oviposition period, longevity, life span, total number of 
Table (2): Effect of treatments with three forms of propolis on the biological aspects of T. urticae and E. africanus

\begin{tabular}{|c|c|c|c|c|c|}
\hline \multirow[b]{2}{*}{ Stages } & \multicolumn{2}{|c|}{ E. africanus } & \multirow{2}{*}{$\begin{array}{c}\text { T. urticae } \\
\text { Nano- } \\
\text { emulsion of } \\
\text { propolis } \\
\end{array}$} & \multirow[b]{2}{*}{ Control } & \multirow[b]{2}{*}{ Sig. } \\
\hline & $\begin{array}{l}\text { Ethanol } \\
\text { extract of } \\
\text { propolis }\end{array}$ & $\begin{array}{c}\text { Hexane } \\
\text { extract of } \\
\text { propolis }\end{array}$ & & & \\
\hline Incubation period & $\begin{array}{c}6.33 \\
\pm 1.91^{\mathrm{a}}\end{array}$ & $\begin{array}{c}7.4 \\
\pm 1.12^{\mathrm{a}}\end{array}$ & $\begin{array}{c}4.00 \\
\pm 1.35^{\mathrm{a}}\end{array}$ & $\begin{array}{c}2.60 \\
\pm 0.38^{\mathrm{b}}\end{array}$ & $* * *$ \\
\hline Active larva & $\begin{array}{c}1.87 \\
\pm 0.22^{\mathrm{a}} \\
\end{array}$ & $\begin{array}{c}1.67 \\
\pm 0.52^{a} \\
\end{array}$ & $\begin{array}{c}1.63 \\
\pm 0.47^{\mathrm{a}} \\
\end{array}$ & $\begin{array}{c}1.53 \\
\pm 0.35^{b}\end{array}$ & $*$ \\
\hline Quiescent larva & $\begin{array}{c}1.1 \\
\pm 0.20^{\mathrm{a}}\end{array}$ & $\begin{array}{c}1.3 \\
\pm 0.21^{a} \\
\end{array}$ & $\begin{array}{c}1.43 \\
\pm 0.37^{\mathrm{a}} \\
\end{array}$ & $\begin{array}{c}0.77 \\
\pm 0.25^{\mathrm{b}}\end{array}$ & $* * *$ \\
\hline Active protonymph & $\begin{array}{c}2.2 \\
\pm 0.45\end{array}$ & $\begin{array}{c}2.27 \\
\pm 0.62\end{array}$ & $\begin{array}{c}2.2 \\
\pm 0.44\end{array}$ & $\begin{array}{c}2.03 \\
\pm 0.25\end{array}$ & ns \\
\hline Quiescent protonymph & $\begin{array}{c}0.77 \\
\pm 0.00^{\mathrm{a}} \\
\end{array}$ & $\begin{array}{c}0.87 \\
\pm 0.22^{\mathrm{a}} \\
\end{array}$ & $\begin{array}{r}1.16 \\
\pm 0.24^{\mathrm{a}} \\
\end{array}$ & $\begin{array}{c}0.91 \\
\pm 0.26^{b} \\
\end{array}$ & $* * *$ \\
\hline Active deutonymph & $\begin{array}{c}3.73 \\
\pm 0.55^{\mathrm{a}} \\
\end{array}$ & $\begin{array}{c}3.79 \\
\pm 0.41^{\mathrm{a}} \\
\end{array}$ & $\begin{array}{c}3.87 \\
\pm 0.37^{\mathrm{a}} \\
\end{array}$ & $\begin{array}{c}2.91 \\
\pm 0.55^{b}\end{array}$ & $* * *$ \\
\hline Quiescent deutonymph & $\begin{array}{c}0.5 \\
\pm 0.00 \\
\end{array}$ & $\begin{array}{c}0.5 \\
\pm 0.00 \\
\end{array}$ & $\begin{array}{c}0.5 \\
\pm 0.00 \\
\end{array}$ & $\begin{array}{c}0.5 \\
\pm 0.00 \\
\end{array}$ & ns \\
\hline Total immature & $\begin{array}{c}10.17 \\
\pm 1.12^{\mathrm{a}}\end{array}$ & $\begin{array}{c}10.4 \\
\pm 0.72^{\mathrm{a}}\end{array}$ & $\begin{array}{c}10.79 \\
\pm 1.26^{\mathrm{a}}\end{array}$ & $\begin{array}{c}8.65 \\
\pm 1.12^{b}\end{array}$ & $* * *$ \\
\hline Adult longevity & $\begin{array}{c}3.27 \\
\pm 0.39^{\mathrm{a}} \\
\end{array}$ & $\begin{array}{c}8.61 \\
\pm 0.23^{a} \\
\end{array}$ & $\begin{array}{c}4.47 \\
\pm 0.43^{\mathrm{a}} \\
\end{array}$ & $\begin{array}{c}12.33 \\
\pm 0.39^{b} \\
\end{array}$ & $* * *$ \\
\hline Life cycle & $\begin{array}{r}16.33 \\
\pm 1.96^{\mathrm{a}} \\
\end{array}$ & $\begin{array}{r}17.80 \\
\pm 1.49^{\mathrm{a}} \\
\end{array}$ & $\begin{array}{c}14.97 \\
\pm 1.91^{\mathrm{a}} \\
\end{array}$ & $\begin{array}{r}11.25 \\
\pm 1.59^{\mathrm{b}} \\
\end{array}$ & $* *$ \\
\hline Generation time & $\begin{array}{c}17.53 \\
\pm 1.96^{\mathrm{a}} \\
\end{array}$ & $\begin{array}{c}18.77 \\
\pm 1.49^{\mathrm{a}} \\
\end{array}$ & $\begin{array}{r}16.47 \\
\pm 1.91^{\mathrm{a}} \\
\end{array}$ & $\begin{array}{r}12.92 \\
\pm 1.35^{\mathrm{b}}\end{array}$ & $* *$ \\
\hline Life span & $\begin{array}{c}19.60 \\
\pm 1.73^{\mathrm{a}}\end{array}$ & $\begin{array}{c}26.41 \\
\pm 2.30^{\mathrm{a}} \\
\end{array}$ & $\begin{array}{r}19.44 \\
\pm 3.49^{\mathrm{a}} \\
\end{array}$ & $\begin{array}{c}23.58 \\
\pm 1.73^{\mathrm{b}}\end{array}$ & $* * *$ \\
\hline
\end{tabular}

eggs/female, number of eggs/\&/day of $T$. urticae, and significantly prolonged the incubation period. El-sayed and Emam, (2021) showed the concentration of $2000 \mathrm{ppm}$ of propolis extract caused the mortality of $98.27 \pm 0.57 \%$ for eggs and $98.25 \pm 0.37$ and $97.42 \pm 0.39 \%$ for larva and nymph stages in comparing with the control.

\section{Efficiency of nano-emulsion of propolis against Varroa destructor}

Tables (3-4) showed that $V$. destructor mites is highly sensitive to nano emulsion of propolis. In the winter season, the efficiency percentage of nanoemulsion of propolis at $4 \%$ reached $100 \%$ compared to control (Table 3). In the autumn season, the efficiency percentage reached $95.62 \%$ at the first spray while reached $94.85 \%$ through 15 days of the first spray compared to 54.16 in control 
Table (3) Efficiency of nano- emulsion of propolis in control of varroa mites through 7 day exposure through winter season

\begin{tabular}{|c|c|c|c|c|c|c|c|}
\hline $\begin{array}{c}\text { Treatments } \\
\text { 1/January } \\
\text { /2021 }\end{array}$ & $\begin{array}{c}\text { No. } \\
\text { of } \\
\text { hives }\end{array}$ & $\begin{array}{c}\text { Natural } \\
\text { fallen } \\
\text { before } \\
\text { treatment }\end{array}$ & $\begin{array}{c}\begin{array}{c}\text { No. } \\
\text { of } \\
\text { dead }\end{array} \\
\text { varroa }\end{array}$ & $\begin{array}{c}\text { Efficiency } \\
\%\end{array}$ & $\begin{array}{c}\text { Mean } \\
\text { Efficiency } \\
\quad \%\end{array}$ & $\begin{array}{c}\text { Ratio } \\
\text { between } \\
\text { fallen } \\
\text { before } \\
\text { and } \\
\text { after } \\
\text { treatment }\end{array}$ & \begin{tabular}{|c|} 
Mean \\
Ratio \\
between \\
fallen before \\
And \\
after \\
treatment
\end{tabular} \\
\hline \multirow[t]{4}{*}{ Treatments } & 1 & 0 & 6 & 100 & \multirow[t]{4}{*}{100} & 6 & \multirow[t]{4}{*}{6} \\
\hline & 2 & 0 & 5 & 100 & & 5 & \\
\hline & 3 & 0 & 4 & 100 & & 4 & \\
\hline & 4 & 0 & 9 & 100 & & 9 & \\
\hline \multirow[t]{3}{*}{ Control } & 5 & 0 & 0 & 0 & \multirow[t]{3}{*}{0} & 0 & \multirow[t]{3}{*}{0} \\
\hline & 6 & 0 & 0 & 0 & & 0 & \\
\hline & 7 & 0 & 0 & 0 & & 0 & \\
\hline
\end{tabular}

experiment (Table 4). Increased toxicity may be due to the dissolution of the resin and wax compounds found in propolis nanoparticles, a more hydrophobic material (Villalobos et al., 2017).

The varroacidal action of natural propolis seems to be paradoxical, since propolis and $V$. destructor is normally found in the beehive, and the mite individuals walk on thin propolis layers throughout the hive. The most probable explanation for why natural propolis does not kill the mites in the beehive is that propolis is insoluble in the beehive's interior since most of the components of propolis are water insoluble. The water-soluble components of propolis comprise about $2.5 \%-6.5 \%$ of the total, based on the origin of propolis (Neunaber, 1995).Therefore, propolis was prepared in the other form such as nano emulsion, which is characterized by its high ability to dissolve in water and oil and its high ability to penetrate the different parts of the beehives due to the small size of its droplets and recording both narcosis and mortality. So, when a concentration of emulsion $4.0 \%$ was prepared in one liter water and sprayed at the rate of $100 \mathrm{ml}$ of the nano-emulsion for each hive, it achieved $100 \%$ effectiveness in the beehives that treated before by abistan strips, which were assumed to be free of mites (average of 6 individuals / beehive) compared to the control that did not record any number of Varroa (zero/ beehive). Žilius et al., (2016) showed that, essential oils in the formulation increased penetration of phenolic compounds.

Treatment of mites with propolis causes narcosis and death. The narcotic effect of propolis on different animals has already been mentioned in the 
Table (4) Efficiency of nano- emulsion of propolis in control of varroa mites through 7 day exposure through automn season

\begin{tabular}{|c|c|c|c|c|c|c|c|}
\hline $\begin{array}{c}\text { Treatments } \\
\text { 9August } \\
\text { /2021 }\end{array}$ & $\begin{array}{c}\text { Number } \\
\text { of } \\
\text { hives }\end{array}$ & $\begin{array}{c}\text { Natural } \\
\text { fallen } \\
\text { before } \\
\text { treatment }\end{array}$ & $\begin{array}{c}\text { Number } \\
\text { of } \\
\text { dead } \\
\text { varroa }\end{array}$ & $\begin{array}{c}\text { Efficiency } \\
\%\end{array}$ & $\begin{array}{c}\text { Mean } \\
\text { Efficiency } \\
\%\end{array}$ & $\begin{array}{c}\text { Ratio } \\
\text { between } \\
\text { fallen } \\
\text { before } \\
\text { and } \\
\text { after } \\
\text { treatment }\end{array}$ & $\begin{array}{c}\text { Mean } \\
\text { Ratio } \\
\text { between } \\
\text { fallen } \\
\text { before } \\
\text { and } \\
\text { after } \\
\text { treatment }\end{array}$ \\
\hline \multirow[t]{4}{*}{ Treatment } & 1 & 1 & 27 & 96.30 & \multirow[t]{4}{*}{95.62} & 27 & \multirow[t]{4}{*}{20.25} \\
\hline & 2 & 2 & 30 & 93.33 & & 15 & \\
\hline & 3 & 1 & 14 & 92.86 & & 14 & \\
\hline & 4 & 1 & 25 & 100 & & 25 & \\
\hline \multirow[t]{3}{*}{ Control } & 5 & 1 & 1 & 0 & \multirow[t]{3}{*}{0} & 1 & \multirow[t]{3}{*}{1} \\
\hline & 6 & 0 & 0 & 0 & & 0 & \\
\hline & 7 & 1 & 1 & 0 & & 1 & \\
\hline \multicolumn{8}{|c|}{15 days after the first spray, the second spray was done, 8/24/2021 } \\
\hline \multicolumn{8}{|c|}{ After 24-h exposure } \\
\hline \multirow[t]{4}{*}{ Treatment } & 1 & 1 & 13 & 92.31 & \multirow[t]{4}{*}{89.70} & 13 & \multirow[t]{4}{*}{10.13} \\
\hline & 2 & 1 & 11 & 90.91 & & 11 & \\
\hline & 3 & 2 & 15 & 86.67 & & 7.5 & \\
\hline & 4 & 2 & 18 & 88.89 & & 9 & \\
\hline \multirow[t]{3}{*}{ Control } & 5 & 2 & 3 & 33.33 & \multirow[t]{3}{*}{27.77} & 1.5 & \multirow[t]{3}{*}{1.83} \\
\hline & 6 & 1 & 2 & 50 & & 2 & \\
\hline & 7 & 1 & 1 & 0 & & 2 & \\
\hline \multicolumn{8}{|c|}{ After 7-d exposure } \\
\hline \multirow[t]{4}{*}{ Treatment } & 1 & 2 & 24 & 91.67 & \multirow[t]{4}{*}{94.85} & 12 & \multirow[t]{4}{*}{23.38} \\
\hline & 2 & 1 & 25 & 96.00 & & 25 & \\
\hline & 3 & 2 & 35 & 94.29 & & 17.5 & \\
\hline & 4 & 1 & 39 & 97.44 & & 39 & \\
\hline \multirow[t]{3}{*}{ Control } & 5 & 4 & 12 & 66.67 & \multirow[t]{3}{*}{54.16} & 3 & \multirow[t]{3}{*}{2.39} \\
\hline & 6 & 3 & 8 & 62.5 & & 2.67 & \\
\hline & 7 & 2 & 3 & 33.33 & & 1.5 & \\
\hline
\end{tabular}

literature (where nano-propolis can use safely for the control of the ectoparasitic mite Varroa destructor at any season during the year. Garedew et al., (2002). mentioned that for reducing the number of inactive components of propolis in hive products, the active varroacidal components of propolis may be isolated and used alone.

In addition, it may be worth investigating the synergistic action of propolis with essential oils already being used as varroacides. If propolis is effective in 
field experiments, and if it has no negative effect on the bees themselves, it may minimize the cost of beekeeping. It was found that miticidal doses of thymolphosphate (ThP) killed adult and larval honey bees under long-term exposure, whereas those same doses did not kill Varroa comparable to the positive control, 50\% thymol (Bohls, 2017). Habeb, (2012) showed that the natural essential roots Viscose inula oils have great efficiency against the varroa, and this is an important sign to stop the using of the pesticides which have a deleterious effect on the environment, bees and consumers of its products. Al-Qurashi and Awad, (2018)mentioned that the hydrophobic composites of propolis extracts is capable of forming a biodegradable semipermeable film on fruit surface that might limit water loss and gas exchange in various fruit. Under field conditions, propolis extract increased the number of fallen mites, but had a greater lethal effect on bee workers in the laboratory than drone larvae extract or sugar syrup. All of the treatments failed to improve bee grooming behavior (Abou-Shaara, 2017).

Conclusively, from these results it be concluded that, propolis can be used as a caricides against plant mites, as well as, against the Varroa colonies in honeybees in the form of nano-emulsion.

\section{REFERENCES}

Abou-Shaara, H. F. (2017). Using safe materials to control Varroa mites with studying grooming behavior of honey bees and morphology of Varroa over winter. Annals of Agricultural Sciences, 62(2): 205-210.

Alencar, S.M.; T. L. C. Oldoni ; I.S.R. Castro; M.L. Cabral ; C.M. Costa; J. A. Cury ; P. L. Rosalen. and M.Ikegaki.(2007). "Chemical Composition and biological activity of a new type of Brazilian propolis (red propolis). J. Ethenopharmacology,113:278-283.

Alexandra, D.; S. Adrian; M. Elena-Alina; N. Monica; L. Virgil-Dacian; L. Diana; D. Cristina-Adriana; M. Danina-Mirela and A. Ersilia (2019).Identification of resveratrol as bioactive compound of propolis from western Romania and characterization of phenolic profile and antioxidant activity of ethanolic extracts. Molecules. 24(18): 3368.

Al-Qurashi, A.D. and M. A. Awad (2018). Postharvest ethanolic extract of propolis treatment affects quality and biochemical changes of 'HindiBesennara'mangos during shelf life. Scientia horticulturae. 233, 520525. 
Ararso, Z.and Legesse, G. (2016). Insecticidal action of honeybees propolis extract against larvae of lesser wax moth. Agric. Biol. J. N. Am., 7(6): 302-306

Bogdanov, S. and Bankova, V. (2017). Propolis: origin, production, composition. The Propolis Book.

Bohls, P. A. (2017). Efficacy of Novel and Optimized Biomiticides for Use Against Varroa destructor in honeybee (Apis mellifera) Colonies. University of California, Davis

Costa, A.; M. Veca; M. Barberis; A. Tosti; G. Notaro; S. Nava. and F.M. Tangorra (2019). Heavy metals on honeybees indicate their concentration in the atmosphere. a proof of concept. Italian Journal of Animal Science. 18(1): 309-315.

Cunha, I., A. C.; F. M. Sawaya; M. T. Caetano; M. C. Shimizu; F. Marcucci; T. Drezza. and P. D. O. Carvalho (2004). Factors that influence the yield and composition of Brazilian propolis extracts. Journal of the Brazilian Chemical Error! Not a valid embedded object. Society. 15, 964-970.

Damiani, N., M. D. Maggi, L. B. Gende, C. Faverin, M. J. Eguara. and J. A. Marcangeli (2010). Evaluation of the toxicity of a propolis extracton Varroa destructor (Acari: Varroidae) and Apis mellifera (Hymenoptera: Apidae). Journal of Apicultural Research; 49(3): 257-264.

Daugsch, A., C. S. Moraes; P. Fort. and Y. K. Park (2008). Brazilian red propolis-chemical composition and botanical origin. Evidence-based complementary and alternative medicine, 5(4), 435-441.

Drescher, N.; A. M. Klein; P. Neumann; O. Yañez and S. D. Leonhardt (2017). Inside honeybee hives: Impact of natural propolis on the ectoparasitic mite Varroa destructor and viruses. Insects, 8(1), 15.

El-sayed, S. M. and Emam, H. M. (2021). Effect of propolis extract (bee glue) on Tetranychus urticae Koch (Acari: Tetranychidae) under greenhouse conditions. Persian Journal of Acarology, 10(3), 299-308.

El-Sayed, Z.I; N. A Omar; A. A. Romeh, (2009). Chemical constituents and biocidal activity of the essential oil of Mentha spicata L. grown in Zagazigregion, Egypt. Research Journal of Agriculture and Biological Sciences, 5(6), 1089-1097.

Fahmy, H. M.; R. E. S. Eldin; E. S. A. Serea; N. M. Gomaa; G. M. AboElmagd; S. A. Salem and A. E. Shalan (2020). Advances in nanotechnology and antibacterial properties of biodegradable food packaging materials. RSC Advances, 10 (35), 20467-20484 
Garedew, A.; I. Lamprecht; E. Schmolz and B. Schricker (2002). The varroacidal action of propolis: a laboratory assay. Apidologie, 33(1), 4150.

Ghisalberti, E.L. (1979) Propolis: a review. Bee World, 60(2): 58-84. Henderson, C.F. and Tilton, E.W. (1955) Tests with acaricides against the brow wheat mite.Journalof Economic Entomology. 48: 157-161.

González-Cabrera, J.; T.G.E. Davies; L.M. Field; P.J. Kennedy and M.S. Williamson (2013). An amino acid substitution (L925V) associated with resistance to pyrethroids in Varroadestructor. PLoS One. 8 (12): e82941. doi:10.1371/journal.pone.0082941.

Habeb, F. (2012). Efficiency study of Inula viscose roots oil against honeybee Parasite (Varroa destructor) in Comparison to Oxalic Acid. Tishreen University Journal for Research and Scientific Studies - Biological Sciences Series 34, (3): 65-76.

Karapetsas, A.; G.P. Voulgaridou; M. Konialis; I. Tsochantaridis; S. Kynigopoulos; M. Lambropoulou; M.I. Stavropoulou; K. Stathopoulou; N. Aligiannis; P., Goussia; A. Bozidis; K. Gardikis; M.I. Panayiotidis and A. Pappa (2019) .Propolis extracts inhibit UVinducedphotodamage in human experimental in vitro skin models.Antioxidant. 8 (125): 1-20.

König, B. and Dustmann, J.H. (1988). Baumharze, Bienenund antivirale Chemotherapie, Naturwiss. Rundsch.2: 43-53.

Lotfy, M. (2006). Biological activity of bee propolis in health and disease. Asian Pac J Cancer Prev. 7(1): 22-31.

Mehta, J.; S.Rayalam; X. Wang (2018). Cytoprotective effects of natural compounds against oxidative stress. Antioxidants, 7(10): 147.

Monteiro, V. B.; M. G. Gondim; D. M. Oliveira; H. A. Siqueira And J. M. Sousa. (2015). Monitoring Tetranychus urticae koch (acari: tetranychidae) resistance to abamectin in vineyards in the lower middle São Francisco Valley. Crop Protection. 69: 90-96.

Moukarab, D. A. A. (2020). Evaluation of antimicrobial activity of manually agitate (nano-chitosan and nano-propolis) against Enterococcus faecalis in comparison with sodium hypochlorite: an in-vitro study.Egyptian Dental Journal, 66(1-January (Fixed Prosthodontics, Dental Materials, Conservative Dentistry and Endodontics).587-596.

Munawar MS.; S. Raja; M. Siddique; S. Niaz and M. Amjad (2009). Th pollination by honeybee (Apis mellifera L.) increases yield of canola (Brassica napus L.). Pak. Entomol ., 31: 103-106. 
Neunaber E. (1995). Phytochemische und mikrobiologischeUntersuchungen von Propolis verschiedenerProvienzen als Beitrag zur Kenntnis derWirkprinzipien in Propolis, Inaugural-DissertationFree University of Berlin, Faculty of Pharmacy,Berlin.

Rincón, R.; D. Rodríguez and E. Coy-Barrera (2019). Botanicals against Tetranychus urticae Koch under laboratory conditions: A survey of alternatives for controlling pest mites. Plants. 8(272):1-51.

Romeh, A. A. and N. A. Omar (2003). Toxicological effects of entomopathogenic fungi, Beauveria bassiana (Balsamo) and Meterhizium anizopliae (Metsch) on the two pytophagous mites, Tetranychus urticae Koch and Eutetranychus africanus (Tucker). J. Appl. Sci., 18 (2): 314-333.

Rosa, A.S.; B. Blochtein and D.K. Lima (2011). Honey bee contribution to canola pollination in Southern Brazil. Sci. Agric. (Piracicaba, Braz.). 68: 255-259.

Santamaria, M.E.; A. Arnaiz; I. Rosa-Diaz; P. González-Melendi; G., Ojeda-Martinez; D.A. Romero-Hernandez; A. Garcia; E. Contreras; E.C. Manuel Martinez . and I. Diaz. (2020). Plant defensesagainst (Tetranychus urticae): (mind the gaps). Plants. 9(4): 464.

Seibert, J. B.; J. P. Bautista-Silva; T. R. Amparo; A. Petit; P. Pervier; J. C. dos Santos Almeida and O. D. H. Dos Santos ( 2019) . Development of propolis nanoemulsion with antioxidant and antimicrobial activity for use as a potential natural preservative. Food. chemistry. 287: 61-67.

Skerl, M.I.S.; M. Nakrst;L. Zvokejl and A. Gregorc ( 2011) . The acaricidal effect of flumethrin,oxalic acid and amitraz against Varroa destructor in honeybee (Apis mellifera carnica) colonies. Acta Vet Brno. 80: 51-56.

Spreafico, M.; F.R. Eördegh; I. Bernardinelli and M. Colombo (2001). First detection of strains of Varroa destructor resistant to coumaphos. Results of laboratory test and field trials, Apidologie .32: 49-55.

Stumpf, N. and Nauen, R. (2001). Cross-resistance, inheritance, and biochemistry of mitochondrial electron transport inhibitor-acaricide resistance in Tetranychus urticae (Acari: Tetranychidae). Journal of Economic Entomology. 94(6), 1577-1583.

Tomczyk, A. and Suszko, M. (2011). The role of phenols in the influence of herbal extracts from (Salviaofficinalis L) and ( Matricaria chamomilla L) on two-spotted spider mite Tetranychus urticae Koch. Biological Letters. 48(2): 193-205. 
Van Leeuwen, T.; J. Vontas; A. Tsagkarakou; W. Dermauw and L. Tirry (2010). Acaricide resistance mechanisms in the two-spotted spider mite Tetranychus urticae and other important Acari: a review. Insect biochemistry and molecular biology. 40(8): 563-572.

Villalobos, K., H. Rojas, R. González-Paz, D. B. Granados, J. GonzálezMasís, J. V. Baudrit. and Y. R. Corrales-Ureña (2017). Production of starch films using propolis nanoparticles as novel bioplasticizer. Journal of Renewable Materials. 5(3-4): 189-198.

Waller, R.A. and D.P. Duncan (1969). A bays rule for symmetric multiple comparison problem. Amer. Stat. Assoc. J. 1485-1503.

Žilius, M.; K. Ramanauskienė; V. Juškaitė and V. Briedis (2016). Formulation of Propolis phenolic acids containing microemulsions and their biopharmaceutical characterization. Evidence- Based Complementary and Alternative Medicine.

\section{فعالية البرويوليس كمبيد أكاروسي}

شيماء منصور الحادق، أحمد علي رميح، نبيل عبد الله عمر، حمة محمد الشرقاوي

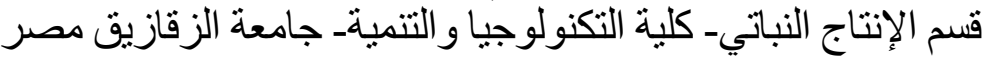

البروبوليس ينتجه نحل العسل وهو عبارة عن خليط راتجي أصفر داكن أو بني من عدة

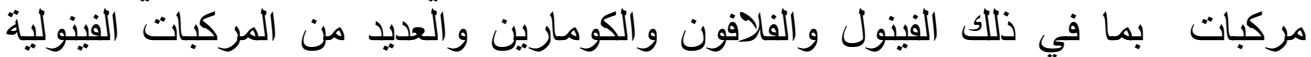
الأخرى. الأكاروسات وخاصة في والأكاروس الطفيليdestructor Anderson and Trueman Varroa في فريدة من نوعها بين مفصليات الأرجل من حيث أنها مقاومة لمجموعة واسعة من المبيدات الأكاروسية

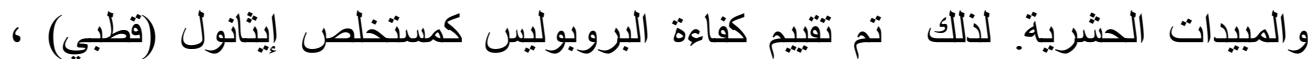
وكمستخلص هكساني (غير قطبي) تجاه للبروبليس تجاه Varroadestructor وT. urticae وكانت النتائج أن مستخلص الإيثانول

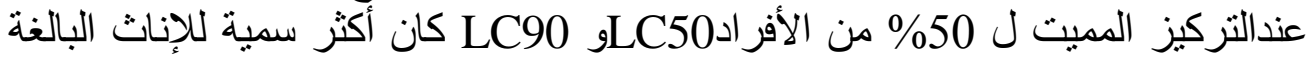
T. urticae للحلم E. africanus من مستخلص الهكسان. أظهرت الإناث البالغة للحنة

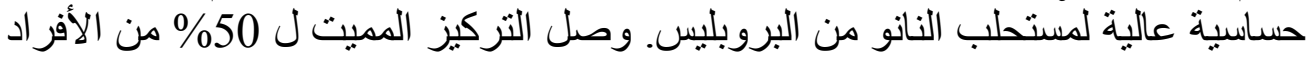

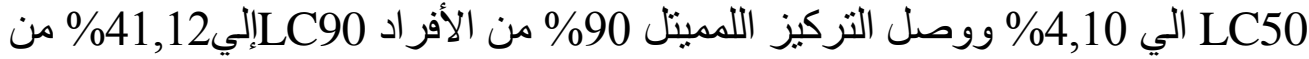


مستحلب البروبوليس النانوي. كانت الجوانب البيولوجية لكلاالنو عين من الأكاروسات أكثر

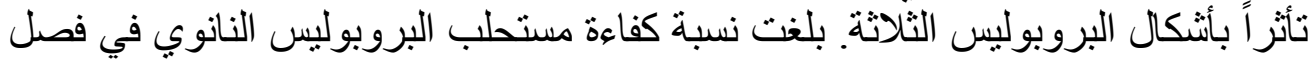

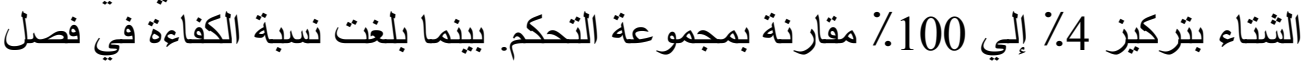
الخريف 65.62\% في الرش لأول مرة و 94.85٪ خلال 15 يوم من الرشة الأولي مقابل 54.16 في تجربة التحكم. التوصية: نستنتج من هذه النتائج أنه يمكن إستخدام البروبوليس كمبيد أكاروسي تجاه

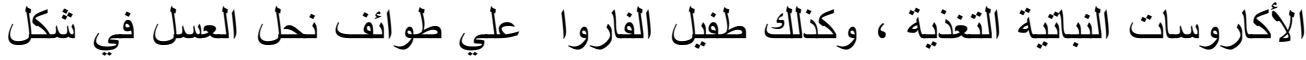

